\title{
THREE SEEMINGLY UNRELATED PROPOSITIONS CONCERNING AUSTRALIA'S IDENTITY AND ECONOMIC PERFORMANCE
}

\author{
by Saul Eslakea \\ Eslake, S.R. 2005 (16:xii): Three seemingly unrelated propositions concerning Australia's identity and economic performance. Papers and \\ Proceedings of the Royal Society of Tasmania 139: 53-60. https://doi.org/10.26749/rstpp.139.53 ISSN 0080-4703. A.N.Z. Bank, \\ Level 10, 100 Queen Street, Melbourne, Victoria 3000, Australia.
}

In three selected respects, Australia's institutions and culture both reflect and influence our national identity and in so doing, it is argued, detract from Australia's economic performance. Australia's tax system favours the accumulation of wealth through borrowing and speculative investment rather than through working and saving. Australia's popular culture values excellence in sport but in little else (reflecting which, governments and business devote resources to the pursuit of sporting excellence but in little else). Finally, Australian governments, like some governments overseas, have responded to the threats perceived to be posed by terrorism and corporate malfeasance in ways that have significantly added to costs and detracted from productivity whilst doing little to reduce the threat from either.

Key Words: Tax reform, negative gearing, double standard, pursuit of excellence, talent, security, corporate governance, productivity.

I'm deeply honoured to be invited to talk to the Royal Society of Tasmania. I'm on the record as saying that if I had thought, as a callow youth, that I could have made a living as an historian then I would have sought to become one. And despite having chosen instead to become an economist, I've remained enough of an amateur historian to be aware of this Society's role in fostering knowledge, particularly but not exclusively in the natural sciences, since its foundation in 1843, the first such Society to be founded outside the United Kingdom. Since I'm neither a scientist nor an academic, and make no claim to have 'pushed out the frontiers of knowledge' even in my own field of economics, I feel particularly humbled and not a little daunted at being invited to speak to such an auspicious gathering.

Rather than making new discoveries in the field of economics, I regard my role as helping, however imperfectly, the corporation for which I work and its customers, and to the extent possible the broader communities within which it operates, better to understand the environment in which they carry out their activities, and thus to make better informed business and investment decisions. In that sense, I'm motivated, as I always have been, by the belief so eloquently expressed by the Nobel Laureate in Economics the late James Tobin, that economics 'offer[s] the hope ... that improved understanding could better the lot of mankind'.

I don't want to overstate the importance of economics in this, or any other regard. I've always thought that Maynard Keynes' assertion that 'the world is ruled by little else' than 'the ideas of economists, both when they are right and when they are wrong'c was an exaggeration, both when he made it in 1936 and since - although the fact that he made it nearly 60 years ago does put into a more appropriate perspective the commonly-made claim that economists have had too much' influence over public policy in recent years.

But I do share the opinion of Paul Krugman - who may well win a Nobel Prize in Economics one day if he spends more time on economics and less time writing polemics against the Bush administration in the columns of the New York Times, well written though they are, and much as I find myself agreeing with many of them - that 'economists may make lots of bad predictions, but they do have a method - a systematic way of thinking about the world that is more true than not, that gives them genuine if imperfect expertise. That is also why lay commentators and other social scientists tend to hate them'd

Tonight I want to step outside my normal 'territory' to speak about three issues which, though seemingly unrelated, in my opinion have, in their different ways, some bearing on the kind of nation and society we are - that is, on our identity - as well as on the performance of our economy.

Because I am stepping outside the 'territory' normally inhabited by economists, I want to emphasise, more strongly than the usual disclaimer implies, that I am speaking solely for myself, and that my views do not purport to represent, and should not be taken as representing, those of my employer.

And I also want to stress that although I am going to disagree, expressly in some instances and by implication in others, with a number of prominent and powerful individuals, that I am not criticising them for having opinions from which I differ.

It is, I think, regrettable that - as I have discovered myself - it is becoming more difficult to express opinions which in some way diverge from those of people in positions of power or authority, or to suggest that some alternative perspective or policy might be worth considering, without that being taken as tantamount to treason, and cause for retribution of some kind against oneself or one's employer. However, that is an issue which, for now at least, I will leave to others to pursue.

Thirdly, I should perhaps emphasise that it is not my intention to say what Australia's identity should be. For any one individual to do so is, I think, quite arrogant; and for a government to attempt to do it is kind of scary. Equally arrogant, I believe, are attempts to suggest that Australia has some kind of monopoly on particular values. We are of course entitled to believe that Australia is 'the best country in the world in which to live' - as I do - but we should be able to do that without claiming that values such as 'equality', 'tolerance', 'respect for the rule of law' or even 'mateship' are somehow uniquely Australian. 
Rather, what I want to do this evening is to spell out how, in my opinion, Australia's present approach to three separate issues influences the kind of society we are, and how - again, only in my opinion - changing that approach could make Australia an even better country in which to live.

Proposition 1: A country's tax system says something important about the kind of society it wants to be, and has an influence on the kind of society it is. Australia's tax system sends the wrong messages and has perverse economic consequences.

The first of these three issues, which I start with only because it is closer to my 'territory' as an economist than the other two, and because quite by coincidence it has assumed particular prominence in recent days, is Australia's tax system.

I want to emphasise at the outset that it is not my purpose to argue that Australians pay too much tax (for what it's worth I don't believe we do); or conversely that we should pay more (I don't believe that either). Rather, I want to talk about the way in which we collect the taxes which we do.

If you were to invite a team of consultants to design a tax system with the explicit objective of discouraging the accumulation of wealth by working and saving, and instead to encourage the accumulation of wealrh through borrowing and acquiring assets expected to appreciate in value at a faster rate than the CPI, they would find it difficult to come up with a better 'solution' than to hand you a copy of the existing Australian income tax legislation. Being consultants, they would probably charge you for several thousand personhours of work; but in practice, they would simply download a copy of the Income Tax Act from the ATO's website and turn it into a book of Powerpoint slides.

Australia's tax system is riddled with exemptions, concessions and deductions which are explicitly designed to favour particular types of income or expenditure over others, and saddled with provisions designed to prevent people from using those exemptions, concessions and deductions in ways that were not intended by those who put them there so as to reduce the amount of tax which they are obliged to pay. That is why Australia's income tax legislation now runs to over 9,000 pages - more, as the Shadow Treasurer Wayne Swan points out, than the Sydney, Melbourne, Brisbane, Perth and Adelaide White Pages combined.

Common and integral to each of the three major rounds of tax reform in Australia over the past two decades has been the principle of broadening the tax base and lowering tax rates:

First, the reforms implemented by the Hawke-Keating Government in the $1980 \mathrm{~s}$, which brought previously untaxed capital gains and fringe benefits into the income tax net, and lowered the top marginal rate from $60 \%$ to $49 \%$. It is interesting to note in passing that the only reduction on the top rate of income tax in the last quarter-century has been implemented by a Labor government.

Second, the Howard Government's reform of the indirect tax system in 2000, which abolished the wholesale sales tax imposed on manufactured goods (at rates of berween 12\% and $45 \%$ ) and replaced it with a goods and services tax (at a rate of $10 \%$ ) applying to virtually all goods and services except basic foods, education and financial services.

And third, the Howard Government's reform of the business income tax system, which lowered the company tax rate from $36 \%$ to $30 \%$ and removed the accelerated depreciation provisions, between 2000 and 2002.

Australia's personal income tax system would be simpler, fairer, more efficient (in the sense of having fewer distortionary effects on the economy) and less prone to avoidance and evasion if all of the exemptions, concessions and deductions with which it is riddled were eliminated and marginal rates lowered: that is, if exactly the same approach were taken to reforming it as has been taken by governments of both major political persuasions to reforming other parts of the tax system.

It is indisputable that these exemptions, concessions and deductions do lead to substantial losses of revenue, cause significant distortions in the economy, favour high-income taxpayers at the expense of lower-income taxpayers (and thus detract from the equity of the tax system), and create opportunities of evasion or avoidance of tax.

Take, as an example, the practice known in Australia as 'negative gearing', under which taxpayers can offset the costs of borrowings undertaken to acquire an investment asset (such as a rental property or a share portfolio) against not only the income produced by that asset, but also against other taxable income such as their salaries. To the best of my knowledge no other country in the world is so generous to leveraged investments as Australia.

The appeal of negative gearing was greatly enhanced by the Government's decision in 2000 to halve the rate at which capital gains (on assets held for more than 12 months) are taxed. It is not at all obvious to me why capital gains should be taxed at a lower rate than income from wages and salaries, other than that this is also the case in some other countries. There's certainly no evidence that it has lifted the level of saving. Nonetheless, this decision was supported by the Opposition.

The halving of the capital gains tax rate effectively converted negative gearing from a strategy which allows tax to be deferred, to one which allows tax to be both deferred and reduced: for taxpayers in the top tax bracket, interest paid is deductible in the year in which it is incurred at $48 \frac{1}{2}$ cents in the dollar; while the capital gains which the borrowings help to facilitate are taxed at a time of the taxpayer's choosing (when he or she sells the asset) at $241 / 4$ cents in the dollar.

According to the Tax Commissioner, in the 2003-04 financial year, 1.4 million Australian taxpayers claimed deductions in respect of rental property investments - an increase of more than $43 \%$ since the 1999-2000 financial year. ${ }^{f}$ That represents nearly $14 \%$ of all taxpayers - a proportion which, according to the Reserve Bank, is more than double that of American taxpayers and more than six times that of British taxpayers.g In 2003-04, claimed deductions on rental property investments exceeded declared rental income by $\$ 2.6 \mathrm{bn}$, a dramatic turnaround from 1999-2000 when income exceeded deductions by $\$ 174 \mathrm{~m}$. It is hard to believe that so many people would have so willingly entered into loss-making propositions but for the powerful incentive to do so provided by the tax system.

Not surprisingly, the introduction of this change led to a significant increase in the use of negative gearing. It is absolutely no coincidence that established house prices in Australia's capital cities rose by an average of over $70 \%$ during the following four years.

Nor is it any coincidence that, since the introduction of this change, the share of Australia's national income devoted to residential investment has been $1 \frac{1}{2}$ percentage points higher than in the preceding decade, and that in 2004 the share of GDP allocated to residential investment exceeded that devoted to productive plant and equipment for the first 
time in Australia's history. ${ }^{\mathrm{h}}$ The only other OECD countries in which this has occurred are New Zealand and Spain.

Since that part of Australia's gross domestic investment which is not financed by domestic saving must be financed by adding to our foreign liabilities, it ought to be of some concern that the tax system provides such powerful incentives to invest in assets whose capacity to contribute to the servicing and ultimate repayment of those foreign liabilities is, for all practical purposes, zero.

Of course, rental property investors are not the only ones to avail themselves of the subsidies provided by the tax system through unrestricted negative gearing and the concessional tax treatment of capital gains. In all, some 930,000 taxpayers declared capital gains in their 2003-04 tax returns, and Treasury estimates that the revenue foregone as a result of those gains being taxed at half the rate applicable to other income amounted to over $\$ 2.5 \mathrm{bn}$ in that year. Taxation statistics for 2001-02 indicate that two-thirds of the capital gains reported in that year accrued to taxpayers in the top tax bracket.

Negative gearing and the concessional tax treatment of capital gains are not the only departures from the principle of neutrality which favour high income earners. For example:

The concessional tax treatment of motor vehicles for fringe benefit taxes - which costs $\$ 1.1 \mathrm{bn}$ annually in revenue foregone - benefits those who take part of their remuneration in the form of employer-provided vehicles, a privilege much more readily available to more highly-paid employees than to those on lower incomes, at the expense of those who cannot or choose not to.

People over the age of 65 - for no reason other than that they are over the age of 65 - will by the 2006-07 financial year be able to earn up to $\$ 25,575$ per annum as singles or $\$ 43,956$ of as couples from investments before having to pay any income tax - an amount which would require income-earning assets of around $\$ 875,000$ earning $5 \%$ pa - whereas people under that age (with no dependants) start paying tax on their wages or salaries at around $\$ 16,650$ as singles and \$30,500-\$31,000 as couples.

Deductions for work-related expenses - which totalled $\$ 10.7$ bn in $2003-04-$ cost at least $\$ 3 \frac{1}{2}-4$ bn in revenue foregone. CPA Australia puts this cost at $\$ 4.7 \mathrm{bn},{ }^{\mathrm{k}}$ Taxpayers in the top tax bracket, who accounted for $13 \%$ of all taxpayers, claimed $24 \%$ of these deductions.

In total, Treasury puts the total cost (in revenue foregone) of 'tax expenditures' at $\$ 31$ bn in 2003-04 - equivalent to $22 \%$ of the total amount collected in income taxes from individuals, companies and superannuation funds - and suggests that this will rise to $\$ 39$ bn by $2007-08 .^{\mathrm{m}}$ The modelling recently commissioned by Liberal MP Malcolm Turnbull suggests that flattening the income tax structure from the present $15 / 30 / 40 / 47 \%$ rate scale to a $15 / 30 / 35 \%$ scale would cost $\$ 5 \frac{1}{2} \mathrm{bn}$; while a $15 / 25 / 35 \%$ scale would cost just over $\$ 15 \mathrm{bn}$ in revenue foregone ${ }^{\mathrm{n}}$.

Personal income tax reform based on lowering marginal rates and broadening the base by removing concessions, deductions and exemptions which are used primarily by high-income taxpayers to reduce and defer tax can thus be readily achieved without pushing the budget into deficit, and without requiring swingeing expenditure cuts.

One does not need to believe, or to argue, that lowering the top marginal rates of income tax will stimulate a torrent of additional work by high-income earners - I don't - or that it will prompt a mass return to Australia by 'tax exiles' currently working in (marginally) lower-tax jurisdictions such as the US or the UK - I don't - in order to believe, and argue - as I do - that a reform program based on lowering marginal tax rates and broadening the income tax base would improve the overall equity of the tax system, reduce compliance costs and increase the likelihood that investment decisions were based on a rational assessment of risk and return rather than on a desire to minimise tax.

Indeed, following the decisions in the most recent Budget to raise the top tax threshold to the point where only $3 \%$ of taxpayers will be paying the top rate from 1 July next year, it is difficult not to wonder whether the resistance to reforms of this nature stems from the fact that those who would be portrayed in the media as deriving the greatest benefit from such reforms (who are not necessarily those who actually would) live almost entirely in safe Liberal electorates in the big cities, or in the safe Labor electorates in the ACT, where their votes are entirely irrelevant to the government's prospects of re-election.

My answer to the challenge posed by the Treasurer to advocates of reform along these lines, "who will pay for the reduction in marginal rates?', is: 'those high income earners who are currently using the various exemptions, concessions and deductions in the income tax system to pay less than the top marginal rate on at least some of their income which would otherwise be taxed at that rate'. In other words, I'm advocating a redistribution of income among the rich - in ways that I believe would be beneficial for the Australian economy - not a redistribution of income to the rich from those less well-off.

Indeed, if one were to abolish all of these loopholes, and to introduce a withholding arrangement for interest and dividend income similar to the PAYE deductions made from wage and salary income - which would not be too difficult since payers of interest and dividends are already required to collect tax file numbers from recipients of these payments and advise the ATO of the amounts paid - then it would probably be possible to relieve most individual income tax payers of the need to file an annual return altogether.

The ATO could send a statement to every taxpayer indicating what he or she had earned from wages and salaries, interest and dividends, how much tax had been deducted from that income, and the refund to which the taxpayer was entitled or the amount of additional tax which was owing. If the taxpayer wished to contest that statement, he or she would then file a return; otherwise, he or she would simply bank or write out a cheque (or the on-line equivalent thereof), as the case may be. Those whose circumstances changed significantly during any one year, and those with business income or other types of investment income (such as rent or capital gains) would obviously still need to be required to file returns; but overall the income tax system would be much simplified.

I can imagine that accountants would not care much for a reform along these lines; but I can't see why anyone else should object.

The same approach, could, incidentally, be applied to State taxation. At present, the second largest source of State tax revenues is stamp duty on land transfers. As State Governments have found over many years, revenues from stamp duty on land transfers are volatile - being dependent on both real estate prices and the volume of real estate transactions - and unpredictable. They also impose a heavy burden on people when, arguably, they are least able to afford it - when they are entering into what for most 
people is the largest single financial commitment they will make in their lives.

Surely it would be both more equitable and, from the standpoint of State Governments, in the interests of better financial management, to replace stamp duties on the transfer of land with a more broadly based land tax. Instead of extracting large amounts of money from a small number of people (in any one year) occasionally, as stamp duties do, State Governments could extract smaller amounts of money from a large number of people regularly - as local governments do through municipal rates. Such a reform might seem politically 'courageous', in the sense intended by Sir Humphrey Appleby, but it is hard to believe that it could not be sold.

There is a lot more that I could say on this subject, including making the point that there are still serious anomalies in the interaction between the income tax system and the social security system which have much more significant adverse effects on labour force participation than the level of the top tax rate. But it is time to move on to my second proposition.

\section{Proposition 2: there is something uncomfortably remin- iscent of the former East Germany about the way in which Australia holds up success in sport as somehow indicative of the superiority of our way of life; and we pay a price for the fact that we do not regard success in other fields as similarly worthy of support, encouragement or pride.}

Let me say straight up, since if I do not it will inevitably be presumed otherwise, that I do not dislike sport. Well, golf bores me senseless, and I'm in a way proud of the fact that l've lived in Melbourne for over 22 years without once having been to a horse race." But I do like cricket and (Australian Rules) football. And indeed one of my fondest dreams is that during my lifetime we will actually have a truly national football competition, one in which every State is represented, and that I will see a Tasmanian team play in an AFL final series.

Nor am I opposed to the public funding of sport. There is a clear economic case for the expenditure of public money on encouraging participation in sport. Apart from the health benefits that accrue from regular exercise, participating in sports teaches the benefits of persistence and team work, the importance of rules and fair play, and (desirably) the capacity to lose with good grace. Even for those who are not active participants, sport plays a vital role in bringing together Australians who might otherwise have little in common.

Nonetheless, the fact that I like (watching) some sports as much as any other Australian (male), and that I readily acknowledge the positive role which sport plays in the lives of Australians, does not prevent me from observing that there is a Great Australian Double Standard at the heart of our national identity.

It is that the pursuit of excellence, the nurturing of talent (at public expense) and the recognition and financial rewards that accompany success are all applauded in the context of sport in Australia, but viewed with disdain in virtually every other field. Sport is one of only three socially acceptable ways to become rich in this country - the others being through popular entertainment or gambling.

Or take the word 'elite'. For an Australian to say of someone that he or she is an elite athlete or sportsperson is, in every context, intended and taken as a complement. But to say, in any other context, that someone is part of an 'elite' or is an 'elitist' is to aver that he or she is part of a privileged minority, out of touch with 'mains(h)tream Aus(h)trayans' (sic), and that his or her opinions on a subject are of no account whatsoever.

Recall the extraordinary outburst of wailing and gnashing of teeth which occurred after the 1976 Montreal Olympics, when Australia not only failed to win any gold medals, but - ignominy piled upon shame! - won fewer medals of any type than New Zealand.

After the ensuing outcry the Fraser Government established the Australian Institute of Sport, on which it and its successors have lavished ample amounts of public funds, and to which young people identified as having the potential to be Olympic champions are sent at public expense - with no requirement to make any repayment to the public purse of the cost of their maintenance and training via HECS-type arrangements as are the mere mortals who attend universities.

This financial year, the Australian Sports Commission (which manages the AIS) will receive $\$ 208 \mathrm{~m}$ of funding from the Commonwealth Budget, an increase of nearly $140 \%$ from the $\$ 83 \mathrm{~m}$ it received in the last year of the Keating Government (how many other agencies, other than security agencies, have had their funding more than doubled since the Howard Government came to office?).

This year's Commonwealth Budget provides an additional $\$ 41 \mathrm{~m}$ over four years 'to support elite sport' (in what other context does the Howard Government explicitly support 'elite' anything?). It also provides a further $\$ 11 \mathrm{~m}$ so that Australian athletes can spend time training in Northern Italy (what other instructional institutions have been assisted with taxpayers' money to establish an overseas campus?').

Contrast this with the reaction to the revelation two years ago that Australia had not one of the top 100 universities in the world. Rupert Murdoch and the Governor of the Reserve Bank, Ian Macfarlane, expressed concern about this less than gold medal-winning performance. But was there a national outcry? Was there a public inquiry? Was there an immediate injection of funds into our university system? No, there was a collective national yawn.

In fact last year the number of Australians attending universities declined, for only the second time in 50 years. To the best of my knowledge no one in government or business has thought this worthy of comment.p

Every year Interbrand produces a list of the top 100 global brands. 9 For each of the past five years, it has been topped by Coca-Cola, Microsoft, IBM and GE, in that order. Brands are the result of creativity and innovation. And brands are valuable: that's why anti-corporate 'activists' like Naomi Klein campaign against them. The top four global brands are valued at between US\$67.5bn and \$47.0bn. Not once in the last five years has there been an Australian name on this list.

Has this caused any kind of national outcry? Not at all. We take comfort in being told that we are 'too small' for any of our brands to be globally significant. But being smaller than Australia, the 16th largest economy in the world, hasn't prevented Switzerland, the 36th largest economy in the world, from having five on this list (Nescafé, Novartis, UBS, Rolex and Nestlé); the Netherlands, the 23rd largest economy in the world, from having three (Phillips, ING and Heineken); Sweden, the 34th largest economy in the world, from having one (Ikea); and Finland, the 49th largest economy in the world, from also having one (Nokia). 
Australia produces a disproportionately high number of Olympic gold medallists, and other sporting champions, relative to our population, because our culture values and applauds success in that arena, and is willing to confer financial support and high social status on those who achieve it.

Conversely, we 'punch below our weight', to employ another sporting metaphor, in other areas such as the arts, sciences and business, because our culture does not value or respect success in these areas.

The Commonwealth, State and Territory governments spent $\$ 1.074 \mathrm{bn}$ on sport and recreation in 2000-01, the latest year for which such figures are available. ${ }^{\mathrm{r}}$ Local governments spent a further $\$ 1.05 \mathrm{bn}$, nearly all of it on venues and grounds.

In the same year, the Commonwealth, State and Territory governments spent $\$ 1.559 \mathrm{bn}$ on 'the arts', plus another $\$ 226 \mathrm{~m}$ on 'art museums'; figures for local government spending on 'the arts' that year are not available, al though in 2003-04 local government spending on 'the arts' totalled $\$ 945 \mathrm{~m}$.

However, these figures for spending on 'the arts' include $\$ 914 \mathrm{~m}$ spent by the Commonwealth Government on 'broadcasting and film', of which $90 \%$ represents funding of the ABC and SBS. Some of this is, of course, spent on broadcasting or televising sport: nothing wrong with that, but spending on 'the arts' it isn't. Nor does spending on news and curtent affairs, worthy and valuable though it is, constitute spending on 'the arts'.

It's not clear from their annual reports how much the $A B C$ and SBS do spend on 'the arts', but it's not unreasonable to suppose that is of the order of $10 \%$ of what they receive from the Commonwealth. On that assumption, total spending on 'the arts' by the Commonwealth, State and Territory governments in 2001-02 was about $\$ 960 \mathrm{~m}, \$ 100 \mathrm{~m}$ less than the amount they spend on sport.

According to a study by the US National Endowment for the Arts - which, admittedly, is now a little dated - Australian governments spend less per capita and less as a percentage of GDP on the arts than governments in any of a representative sample of $10 \mathrm{OECD}$ economies other than the United States (where, of course, there is a much higher level of business and private support for the arts) and (rather surprisingly) Ireland. ${ }^{\mathrm{r}}$

Yet the case for public spending on the arts is surely no less compelling than that for public spending on sport. Indeed, even President George W. Bush has acknowledged that:

\footnotetext{
"the arts and humanities serve as an incomparable mirror and a record of humanity's response to the joys, tragedies, and mysteries of life. They help us better understand ourselves and our world. And they are essential to preserving and celebrating our democratic way of life."u
}

Economists understand this too. Maynard Keynes, in his last broadcast as Chairman of the Arts Council of Great Britain, ten months before he died, said:

"The artist ... leads the rest of us into fresh pastures and teaches us to love and to enjoy what we often begin by rejecting, enlarging our sensitivity and purifying our instincts."v
And of course (most) artists create something which continues long after their death, which (memories aside) is not the case with sportspeople.

The preference for spending on sport than on the arts is even more pronounced in the business sector than in the public sector.

In 2000-01, the latest year for which figures are available, Australian businesses gave $\$ 628 \mathrm{~m}$ to sport and recreation by way of donations or sponsorship, representing $43 \%$ of their total donations and sponsorship expenditures, compared with less than $\$ 70 \mathrm{~m}$ to the arts and culture (and, for that matter, compared with $\$ 339 \mathrm{~m}$ to community service and welfare)."

This strong bias towards sport on the part of business people extends beyond where they spend their shareholders' funds. As Ralph Kerle of the Centre for Cultural Studies and Analysis points out:
"rather than use arts as their inspirational role models for creativity, corporate leaders exhort their senior managers to embark instead on a quest to succeed and find new heights in performance by learning from Australian sporting heroes ... a sporting champion and his [sic] mindset represent the least threatening metaphor for commercial innovation and creativity." ${ }^{\prime}$

Australian governments do spend more on research and development than they do on sport. In 2000-01 the Commonwealth, State and Territory governments spent $\$ 2.4 \mathrm{bn}$ on R\&D - slightly more than half of it on plant or animal research.y Businesses spend even more on R\&D than governments - nearly $\$ 5$ bn in 2000-01 - although they give much less to support R\&D activities by way of donations and sponsorship than they do for sport. However, total Australian spending on R\&D, including that by higher education institutions, is smaller as a percentage of GDP than 15 of the 27 OECD countries.

If anything, the tendency to exalt excellence in sport above excellence in any other field has increased in recent years. A search of the Australian Honours List reveals that of the 22,154 ACs, AOs, AMs and OAMs awarded since their inception, 1,775 or $8.0 \%$ have been for 'services to sport' or to particular sports. This is in addition to the 18,002 recipients of the Australian Sports Medal. But in 2004, the proportion of the recipients of these awards who received them for sport was 10.4\%; and in 2005 it was $15.8 \%$.

Twelve of the 50 'Australians of the Year' since that award was instituted in 1964, and ten of the 26 'Young Australians of the Year' since 1979, have been sportspeople; in the past eight years, half of the 'Australians of the Year' have been sports people.

Let me conclude rhis discussion of my second proposition by emphasising that I do not begrudge successful sports people the support they have received from governments; or the social standing, high incomes and wealth which they have attained as a result of their achievements. I just wish that as a nation we were as willing to identify and invest in people with the potential to excel in the arts and the humanities, in the sciences, and, yes, in industry and commerce, as we do for people with the potential to excel in sports; and that we were as forthcoming in our recognition of, and as tolerant of the financial rewards that come to, those who do achieve great things in other fields. If we 
did, there would be more of such people, and Australia as a nation would be much the better for it.

Proposition 3: Australian governments reacted to two of the great shocks of the twenty-first century (thus far) - terrorism and corporate malfeasance - in ways that have adversely affected the Australian economy without materially reducing the threat posed by either of these developments.

The first five years of the twenty-first century have brought two great shocks to the Western world of which Australia is firmly a part. The first of these is the terrorist attacks on New York and Washington of September 11, 2001, and the subsequent atrocities in Bali in October 2002, Madrid in March 2003, and most recently in London in July 2005. The second is the succession of corporate scandals which erupted in the United States in 2002 with the collapses of Enron, WorldComm, and other companies as a result of demonstrable malfeasance on the part of executives of those companies, and which have had parallels in other countries including Australia. To be sure, these corporate scandals have not entailed the loss of any lives. But they have certainly entailed considerable losses of wealth, including in some cases people's entire life savings, and - like the terrorist attacks - have occasioned a great deal of soul-searching.

One common factor linking both of these shocks is that governments in many parts of the world, including Australia, have felt compelled to be seen to be doing something about them.

Of course I am not saying they should have done nothing about them. What I do want to say, however, is that a good deal of what they have done about both of them has been either ineffectual, or counter-productive, or both.

In the aftermath of September 11, Australia's governments, like governments in other parts of the world, have introduced an enormous amount of legislation and regulation ostensibly designed to 'improve security' and reduce the likelihood of their citizens being killed or injured as a result of atrocities such as those which took place on that date.

We have been repeatedly told that our right "not to be killed in a terrorist attack' trumps whatever other rights our governments believe must be circumscribed in order to uphold this right - although we are never told the bases on which our governments reach that conclusion, ostensibly because to do so might 'compromise' their intelligence sources. These sources are, presumably, the same ones that failed to warn our governments about September 11, October 12, or any of the other terrorist atrocities that have since taken place.

To the same end we are expected to endure tedious delays and in some cases humiliating intrusions into our personal spaces at airports, to tolerate increased surveillance by closed-circuit TV cameras at sporting arenas and in other public places, to accept greater scrutiny of our financia transactions, to have reduced access to public buildings such as our Parliament Houses, to pay more for our airfares and to have more of our taxes diverted to security agencies. And of course we are not supposed to complain about any of these things.

I think that I am more likely to die as a result of a terrorist atrocity than I thought I was before September 11,2001 - although whether I objectively am more likely to die that way, or am simply more aware of the possibility, I can't really say. For what it's worth, I think that I, as an
Australian, am (marginally) more likely to die in a terrorist incident as a result of Australia's participation in the war in Iraq - although that doesn't mean I think Australia was necessarily wrong to participate in that war, any more than I would have thought had I been alive in 1939 that it would have been wrong to participate in the war against Hitler because that made us more likely to be targeted by the Japanese.

However, I am singularly unconvinced that I am any less likely to die as a result of anything that any government has done since September 11, 2001 with the ostensible aim of reducing that probability. Indeed, I am a little troubled by the thought that I am now more likely to be shot in the head by trigger-happy police whilst innocently riding on the London Underground (or some other means of transportation) than I was previously.

It seems to me that the 'security' procedures on which governments have insisted at airports are a reaction to the modus operandi of previous terrorist incidents rather than in thoughtful anticipation of what they might do next. Thus, I'm sure that if Richard Reid had scratched his nose, rather than his shoes, on American Airlines Flight 63 from Paris to Miami on December 22, 2002, security officials would be shining laser beams up our nostrils every time we go to catch a flight rather than making us take off our shoes.

My scepticism about the effectiveness of most of these measures is reinforced by the observation that they are so inconsistently applied. If, for example, I wanted to blow up an aeroplane flying between Wynyard or Devonport (on Tasmania's north-west coast) and Melbourne, or to hijack such an aeroplane and fly it into the Rialto Building in Melbourne - and let me hasten to add I have no such intention - then I would face no greater obstacle to such an evil plan today than I would have on September 10, 2001. If, on the other hand, my conscience got the better of me during the flight and I abandoned my evil intent, then I and my bombs would be intercepted on entry into Tullamarine.

It's not clear to me why the lives of those passengers travelling between any of Australia's capital cities or between them and other cities such as Cairns and Townsville should be more worthy of protection from the evil depredations of terrorists than those travelling from Wynyard, Devonport or any of the other regional airports around the country - since cost seems to be no object at major city airports. But it does make me more than a little dubious about the real effectiveness of the measures which have been put in place at major airports.

One very apparent consequence of our governments' desire to be seen to be doing something in response to the events of September 11, 2001 is that, in airports and in many other buildings and facilities besides, there are now employed thousands of people who do nothing, except prevent those who are doing something from doing it as quickly and cheaply as they otherwise would.

Exactly how many thousands is not possible to say, at least in Australia, since our employment statistics are not available in sufficiently rich detail to draw any unequivocal inferences. However, US employment data, which are available in much more granular detail than is the case in Australia (and for free) indicate that the number of people employed as 'security guards' and in 'airport operations' (other than pilots, air traffic control, baggage handlers and check-in clerks) rose by $8.0 \%$ between June 2001 and June 2005 , compared with an increase in total employment of 
$1.2 \%$ over the same period. I would be very surprised if the corresponding Australian figures were not of the same order of magnitude.

The same general observations can be made of governments' responses to the various instances of corporate malfeasance that have been exposed in the US, Australia and elsewhere in recent years.

It is an unfortunate fact of life that some people are dishonest, that some people are greedy, that some otherwise good people succumb to temptation and that some of these people end up in business.

No amount of legislation or regulation can prevent this, any more than the fact that murder has been a criminal offence carrying the most severe penalties permissible under the law since time immemorial has prevented murders from occurring. But it is also true that those who have been exposed as perpetrators of various corporate misdeeds have been charged, and in most cases convicted, under laws that were in existence before those crimes were committed.

Yet that hasn't stopped governments, including our own, from unleashing a torrent of new legislation and regulation with the purported aim of ensuring that such misdeeds can never recur.

I can't put this any better than my own Chief Executive Officer, John McFarlane, who last week said:

"Just because some companies get into trouble with regulators it doesn't mean everyone else is likely to do so. Just because some companies go bust, it doesn't mean the system is broken. Failure of weak companies is a normal part of the market operating effectively. Unfortunately the response tends to be overreaction and proscriptive, and it is time to lighten up to the rules that really matter." ${ }^{2}$

Sarbanes-Oxley (which is a law passed by the United States Congress, but whose provisions extend extra-territorially to any corporation whose shares are traded on a US stock exchange, or who issue securities in the US), our own CLERP 9, International Financial Reporting Standards (IFRS) and other recent legislative or regulatory impositions have required the employment of hundreds (if not thousands) of additional people to prepare thousands of additional pages of figures and statements which no one is going to read and will make no practical difference to the likelihood that corporate malefactors will be deterred or detected.

It may not be entirely coincidental that the upsurge in productivity-stifling regulation in the areas of security and corporate governance over the past four years has coincided with a dramatic reversal in productivity growth in Australia.

Output per hour worked in what the Australian Bureau of Statistics terms the 'non-farm market sector', the most widely used measure of labour productivity in Australia, rose at an average annual rate of nearly $3 \%$ over the decade ended the December quarter 2003. But since the March quarter of 2004, this measure of labour productivity has fallen by $2.5 \%$. This is the first decline in this measure of productivity since 1986.

Some slowdown in labour productivity growth over the past 18 months or so would not have been surprising, since economic growth (as measured by real GDP) has slowed from $4 \frac{1}{2} \%$ pa to about $2 \%$ pa over this period.

Typically, productivity growth slows when the economy begins to slow, because most employers are reluctant to start laying off workers until they are sure that the slowdown is not a passing phase. However, the magnitude and duration of the divergence between economic growth and employment growth (which has accelerated from less than $2 \%$ pa to $3 \frac{1}{2} \%$ pa) over this period has been too large to be explained by the normal cyclical behaviour of productivity growth.

It is possible that the abrupt decline in productivity reflects an understatement of economic growth, for some reason, that may be corrected by future revisions to previously published data (employment statistics are typically not subject to significant revisions).

It is also plausible that the absence of any significant productivity-enhancing reforms since the industrial relations changes and waterfront reforms of 1998 could account for some slowing in productivity growth - although that does not really explain why productivity should have dropped so abruptly since 2003 .

I would also accept that if the splurge of regulation relating to security and corporate governance had actually contributed materially to improvements in security and corporate governance, then a (hopefully) temporary setback to productivity growth might be an acceptable price to pay - just as I can accept that some loss of productivity growth may be an acceptable price to pay for improved environmental outcomes. But, as I have already observed, I am profoundly sceptical that the increased regulation in these areas has contributed to any meaningful improvement in security or corporate governance.

Rather, governments' responses to these issues suggests the re-emergence of an attitude that 'more regulation is the solution to issues that arise' (as John McFarlane put it last week), which I had rather hoped Australia had grown out of over the past two decades.

This evening I've strayed way out of my normal 'territory' as an economist, and made observations on matters where economists are not normally regarded as possessing any special insights - although I have sought where possible to buttress them by reference to evidence or to impeccable sources.

Perhaps in that context I can take some comfort from the view expressed by no less an authority than the Treasurer earlier this year that bank economists 'seem to be absolute experts on everything these days' ${ }^{\text {ab }}$

But the unifying theme I have tried to weave through these three seemingly un-related propositions is that, in their different ways, they tell us something about our priorities, about our identity as a nation and as a society.

Do we really want to be a nation in which borrowing and speculation are more richly rewarded than working and saving, as our personal income tax system implies?

Do we really aspire to be a nation in which the only legitimate context for the pursuit of excellence is in sports, as the way in which our governments and our businesses allocate the funds available to them suggests, and as the way in which we confer honour and respect conveys?

Do we really wish to be a nation in which our citizens are subject to ever-increasing restrictions on our freedoms of movement, of speech, from covert surveillance, and from detailed regulatory oversight, so that our governments can feel satisfied that they are seen to be 'doing something' about every problem that emerges, as their responses to terrorism and corporate scandals suggest?

My answer to each of these questions is an emphatic no. But, as is often the case, I make no claim to be speaking on behalf of anyone else. 
(Endnotes)

a Saul Eslake is Chief Economist of the Australia and New Zealand Banking Group Ltd. However, and to a greater extent than is usually the case, the views expressed in this paper are entirely his own, and do not purport to be (and should not interpreted as) representing those of his employer or any of its other executives.

b James Tobin, 'Autobiography' (1981), at <www.nobel. se/economics/laureates/1981/tobin-autobio.html>

c John Maynard Keynes, The General Theory of Employment, Interest and Money (London: Macmillan, 1936), p. 383.

d Paul Krugman (2000), 'Why I Am an Economist (Sigh) - Notes During Textbook Revision', at <http://web.mit. edu/krugman/www/Serfdom.htm>.

e Wayne Swan, MP, 'Bridging the Ambition Gap', Speech to the Investment and Financial Services Association (Sydney: 26 August 2005), p. 15.

f Australian Taxation Office, Compliance Program 2005-06, p. 10; Taxation Statistics 2002--03, Table 7.

$g$ Reserve Bank of Australia, Submission to the Productivity Commission Inquiry on First Home Ownership (Sydney: November 2003), p. 19.

$h$ These calculations are based on nominal rather than real values (so as to capture the impact on prices as well as volumes) and exclude the quarters affected by the introduction of the GST.

i Commonwealth Treasury, Tax Expenditures Statement 2004 (Canberra: January 2005), p. 9.

j Kerrie Bremmer, 'Net tax thresholds for Australian Families', in Commonwealth Treasury, Economic RoundUp (Canberra: Winter 2005), p. 46.

k CPA Australia, Reforming Australia's Tax System - A Model for the Future (Melbourne: 2004).

1 Based on calculations by John Freebairn, 'Income Tax Reform: Base Broadening to Fund Lower Rates', in Peter Dawkins and Michael Stutchbury (eds), Sustaining Prosperity (Melbourne University Press, 2005), p. 129 and ATO, op. cit.

m Commonwealth Treasury, op. cit., p. 8.

n Malcolm Turnbull, MP, and Jeromey Temple, Taxation Reform in Australia: Some Alternatives and Indicative Costings (August 2005), pp. 19 and 46.

o Call me a spoilsport, if you will, but I am troubled by the fact that if a horse is any good it will generally be required to carry enough lead to prevent it from doing as well as it otherwise would. This apparently makes for more interesting betting, but it is hardly a test of a good horse. How interesting would the $400 \mathrm{~m}$ or $1500 \mathrm{~m}$ freestyle events be if Ian Thorpe or Grant Hackett were required to have 10 kilos of lead sewn into their lycra swim suits?

p It has been noted by Wayne Swan (op. cit., p. 14), Jenny Macklin and Craig Emerson.

q See Business Week online, <http://bwnt.businessweek. $\mathrm{com} / \mathrm{brand} / 2005 />$.

$r$ Australian Bureau of Statistics, Sport and Recreation Funding by Government (catalogue no. 4147.0, November 2002), p. 5.

$s$ ABS, Cultural Funding by Government (catalogue no. 4183.0, August 2005), p. 6.

$t$ National Endowment for the Arts, International Data on Government Spending on the Arts, Research Note \#74 (January 2000), Table 1 . The data in this study relate to the mid-1990s. u At an award ceremony honouring recipients of the National Medal of the Arts, 22 April 2002.

v John Maynard Keynes, 'The Arts Council: Its Policy and Hopes', broadcast on the BBC, 12 July 1945; cited in Robert Skidelsky, John Maynard Keynes: Fighting for Britain 1937-1946 (London: Macmillan, 2000), p. 294.

w ABS, Generosity of Australian Businesses (catalogue no. 8157.0, June 2002), p. 6.

x Ralph Kerle, 'We May Be the Lucky Country - but Not the Creative Country', Company Director (Australian Institute of Company Directors, October 2004), p. 16.

y ABS, Research and Experimental Development-All Sector Summary (catalogue no. 81 12.0, September 2004). This publication includes figures for 2002-03 but I focus here on the 2000-01 data for consistency with the latest available for spending on the arts and sport.

$z$ On-line at <www.itsanhonour.gov.au>.

aa John McFarlane, 'Challenging the Role of Corporations in Society', Address to the University of Melbourne 'Town and Gown' Dinner (31 August 2005), p. 11.

ab Hon. Peter Costello, MP, at a press conference in Melbourne on 27 April 2005: on-line at <http://www. treasurer.gov.au/tsr/content/transcripts/2005/048.asp $>$.

(accepted 9 October 2005) 